\title{
Antarctic Skuas as bioindicators of local and global mercury contamination
}

Erli Schneider Costa 1, 2, 4, ", Maria Mercedes Santos ${ }^{3}$, Nestor Rubem Coria ${ }^{3}$, João Paulo Machado Torres ${ }^{4}$, Olaf Malm ${ }^{4}$ and Maria Alice dos Santos Alves ${ }^{2,1}$

' Programa de Pós-Graduação em Ecologia, Universidade Federal do Rio de Janeiro (UFRJ),

Caixa Postal: 68.020. Ilha do Fundão, Rio de Janeiro, RJ, Brazil. CEP: 2194I-540.

2 Universidade do Estado do Rio de Janeiro (UERJ). Departamento de Ecologia, Laboratório de Ecologia de Aves, Rua São Francisco Xavier, 524. Maracanã, Rio de Janeiro, RJ, Brazil. CEP: 20550-0II.

${ }^{3}$ Instituto Antártico Argentino (IAA), Depto. Ciencias Biológicas - Proyecto Aves, Cerrito 1248.

Buenos Aires, Argentina. CIOIOAAZ.

${ }^{4}$ Universidade Federal do Rio de Janeiro (UFRJ), Centro de Ciências da Saúde, Instituto de Biofísica Carlos Chagas Filho, Laboratório de Radioisótopos Eduardo Penna Franca. Ilha do Fundão, Rio de Janeiro, RJ, Brasil. CEP: 2 I 494 I-900.

* Actual Adress: Programa de Pós-Graduação em Ambiente e Sustentabilidade. Universidade Estadual do Rio Grande do Sul (UERGS). Unidade Hortências, São Francisco de Paula, Rio Grande do Sul, Brazil. E-mails: erli-costa@uergs.edu.br; mechasantos@yahoo.com.ar, ncoria@dna.gov.ar; jptorres@biof.ufrj.br; olaf@biof.ufrj.br; masaal@globo.com

\section{Abstract}

Mercury $(\mathrm{Hg})$ is a non-essential metal, sometimes extremely toxic, and its presence in the food-web may threaten the wildlife. In seabirds, even low levels of $\mathrm{Hg}$ can reduce egg production and the chances of embryos and chicks survival; high levels of this element lead to erratic behavior, loss of appetite and weight, and cellular damages in organs as kidneys can be detected. According to some authors, among 50 to $93 \%$ of the total $\mathrm{Hg}$ accumulated by the birds through diet can be excreted throughout the feathers during the molting process. In this way, feathers can be used as an excellent non-invasive biomonitor. The objective of this paper was to compared mercury $(\mathrm{Hg})$ levels in feathers of adults and chicks of Catharacta maccormicki ( $\mathrm{Cma}$ ) and $\mathrm{C}$. lonnbergi (Clo) sampled in the Antarctic Peninsula, to identify biomonitors of $\mathrm{Hg}$ to the region using non-invasive samples methods. We found $\mathrm{Hg}$ significantly higher levels in adults of Cma comparing with Clo adults $\left(U^{\prime}=841.00, p<0.01\right)$ and also with chicks of both species $(q>3.398, p<0.01)$. We did not find significant differences comparing Clo adults and chicks of both species $\left(U^{\prime}=16.00, p<0.05\right)$, and comparing Cma breeding in different areas $(q>3.398, p<0.05)$ or $\mathrm{Clo}\left(\mathrm{U}^{\prime}=62.00, \mathrm{p}<0.05\right)$. The $\mathrm{Hg}$ levels variation may be justified mainly by differences in migration patterns. The adults of the species that migrate to more polluted areas (Cma) presented the highest levels of $\mathrm{Hg}$ and can be considered a promising indicator of global contamination. In another way, Clo and chicks of both species are good indicators of local $\mathrm{Hg}$ contamination, suffering the direct influence of contamination in the Antarctic environment.

Keywords: Biomonitoring. Pollutants. Catharacta skuas. Áreas de reprodução. Indicador global.

\section{Resumo}

\section{Skuas Antárticas como bioindicadores de contaminação local e global de mercúrio}

O mercúrio $(\mathrm{Hg})$ é um metal não essencial, por vezes extremamente tóxico, e sua presença na cadeia alimentar pode ameaçar a vida selvagem. Nas aves marinhas, mesmo níveis baixos de $\mathrm{Hg}$ podem reduzir a produção de ovos e as chances de sobrevivência de embriões e filhotes. Altos níveis desse elemento levam a comportamento irregular, perda de apetite e de peso e pode causar danos celulares nos órgãos, como os rins. Segundo alguns autores, entre 50 e $93 \%$ do total de $\mathrm{Hg}$ acumulado pelas aves através da dieta pode ser excretado nas penas durante o processo de muda. 
Dessa forma, as penas podem ser usadas como um excelente biomonitor não invasivo. $O$ objetivo deste trabalho foi comparar os níveis de mercúrio $(\mathrm{Hg})$ em penas de adultos e filhotes de Catharacta maccormicki (Cma) e C. lonnbergi (Clo) amostrados na Península Antártica, para identificar biomonitores de $\mathrm{Hg}$ na região usando métodos não invasivos de amostragem. Encontramos níveis significativamente mais elevados de $\mathrm{Hg}$ em adultos de Cma em comparação com adultos de Clo $(U$ ' $=841,00, p<0,01)$ e também em filhotes de ambas as espécies $(q>3,398, p<0,01)$. Não foram encontradas diferenças significativas de níveis de $\mathrm{Hg}$ na comparação entre adultos e filhotes de Clo de ambas as espécies $(U$ ' $=16,00, p<0,05)$ e em filhotes de Cma em diferentes áreas $(q>3,398, p<0,05)$ ou Clo $(U$ ’ $=62,00$, $\mathrm{p}<0,05)$. A variação dos níveis de $\mathrm{Hg}$ pode ser justificada principalmente por diferenças nos padrões de migração. Os adultos das espécies que migram para áreas mais poluídas $(\mathrm{Cma})$ apresentaram os maiores níveis de $\mathrm{Hg}$ e podem ser considerados um indicador promissor de contaminação global. Por outro lado, Clo e filhotes de ambas as espécies são bons indicadores da contaminação local por $\mathrm{Hg}$, sofrendo a influência direta da contaminação no ambiente antártico.

Palavras Chaves: Biomonitoramento. Poluentes. Catharacta skuas. Breeding sites. Global indicator.

\section{Introduction}

Mercury $(\mathrm{Hg})$ is a non-essential metal, sometimes extremely toxic, and its presence in the food-web may threaten the wildlife (BLÉVIN et al., 20I3; GRANDJEAN et al., 20I0; SCHEUHAMMER et al., 2007). In marine systems such as the Southern Ocean, most biologically available mercury (methylmercury) comes from current-driven transfer from coastal waters, in situ production by microbes, or from the upwelling of deep water (COSSA et al., 20I I). Methylmercury ( $\mathrm{MeHg}$ ) is accumulated in aquatic food chains and may become dangerous to wildlife (WHO, 1976). In seabirds even low levels of $\mathrm{Hg}$ can reduce the egg production and the chances of embryos and chicks survival; high levels of this element lead to erratic behavior, loss of appetite and weight, and cellular damages in organs as kidneys can be recorded (AMAP, 2002, VARIAN-RAMOS, 20I4).

Considered as a "pristine" environment the primary sources of $\mathrm{Hg}$ in Antarctic are human activities, long term atmospheric transportation, and natural events as "summer's deglaciation" period in which $\mathrm{Hg}$ levels increase to rates as high as the ones observed in industrialized regions (BARBAGLI, 2008; SPROVIERI et al., 2002; COSSA et al., 20I I). Antarctic seabirds are more exposed to $\mathrm{Hg}$ bioaccumulation than terrestrial animals because they are top predators feeding on organisms that concentrate inorganic $\mathrm{Hg}$ or MeHg phyto and zooplankton (WALSH, 1990; FURNESS; CAMPHUYSEN, 1997; BURGER; GOCHFELD, 2004; BARGAGLI, 2008).

A higher proportion of $\mathrm{MeHg}$ elimination in birds happens during the molt, and to a small and no significant degree during egg posture (HONDA et al., 1986; FURNESS et al., 1990; THOMPSON et al., 199I) also, inorganic Hg could be eliminated by feces (FURNESS et al., 1995). According to Burger (1993), among 50 to $93 \%$ of the total $\mathrm{Hg}$ accumulated by the organism through diet can be excreted throughout the feathers during molting. Another advantage of using feathers to monitor this element is that the $\mathrm{Hg}$ trapped on the feather suffers no influence of external deposition (VEERLE et al., 2004; GOEDE; DE BRUIN, 1984) since the $\mathrm{Hg}$ concentration in feathers represents $\mathrm{Hg}$ blood levels of the organism obtained by feeding. Because of its association with keratin, the $\mathrm{Hg}$ inside the feathers do not change, even when these are exposed to extreme weather conditions, ultraviolet radiation, and other factors that could cause changes in the levels of $\mathrm{Hg}$ (APPELQUIST et al., 1984). This characteristic makes feathers an excellent archive to assess the exposure of birds to $\mathrm{Hg}$.

For the present study, we sampled two Antarctic seabird species, the skuas $C$. maccormicki and $C$. lonnbergi, that are top predators and have a wide distribution in the studied region (WATSON, 1975; AINLEY et al., 1990; COSTA; ALVES, 2012). These species also have different migration patterns, C. maccormicki migrates up to the Northern Hemisphere during the austral winter, while $C$. lonnbergi features a more localized migration, remaining in the Southern Hemisphere, moving to South America and South Africa (KOPP et al., 20II). The mobility of seabirds can be a disadvantage if we intend to use them as local bioindicators, but it can be an advantage if the objective is to use them as a sizeable spacial scale or global reference (BURGER; GOCHFELD, 200I).

We compared $\mathrm{Hg}$ levels in feathers of adults and chicks of South Polar and Brown Skua (C. maccormicki and $C$. lonnbergi) in three study areas of the Antarctic Peninsula, in order to assess differences in levels of contamination among species, chicks and adults and also comparing breeding areas. Since the sampled 
species differ in feeding and migratory habits, we tested the following hypotheses: I. Adults of both species have different feather $\mathrm{Hg}$ concentrations; 2 . $\mathrm{Hg}$ concentrations differ significantly among adults and chicks between species; 3 . Adults and chicks for the same species present no significant difference in $\mathrm{Hg}$ levels in different breeding areas.

\section{Material and methods}

\section{Study area and data sampling}

We collected the samples in three areas of Antarctic Peninsula: Admiralty Bay $\left(62^{\circ} 05^{\prime} \mathrm{S}, 58^{\circ} 25^{\prime} \mathrm{W}\right)$, Potter

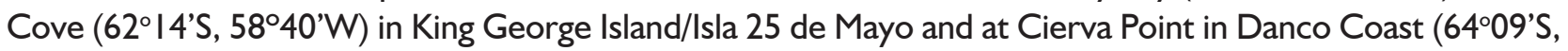
$60^{\circ} 58^{\prime} \mathrm{W}$ ) (Fig. I). The field campaign took place during the austral summer of 2007/2008 (December 2007 to January 2008), 2009/20 I0 (January 2010 to March 20 I0) and 20 I0/20I I (December 20 I 0 to March 20I I). The areas are divided into two regions across which the ranges of these two skuas species overlapping: the South Shetlands Islands and the Western Antarctic Peninsula (Fig. I).

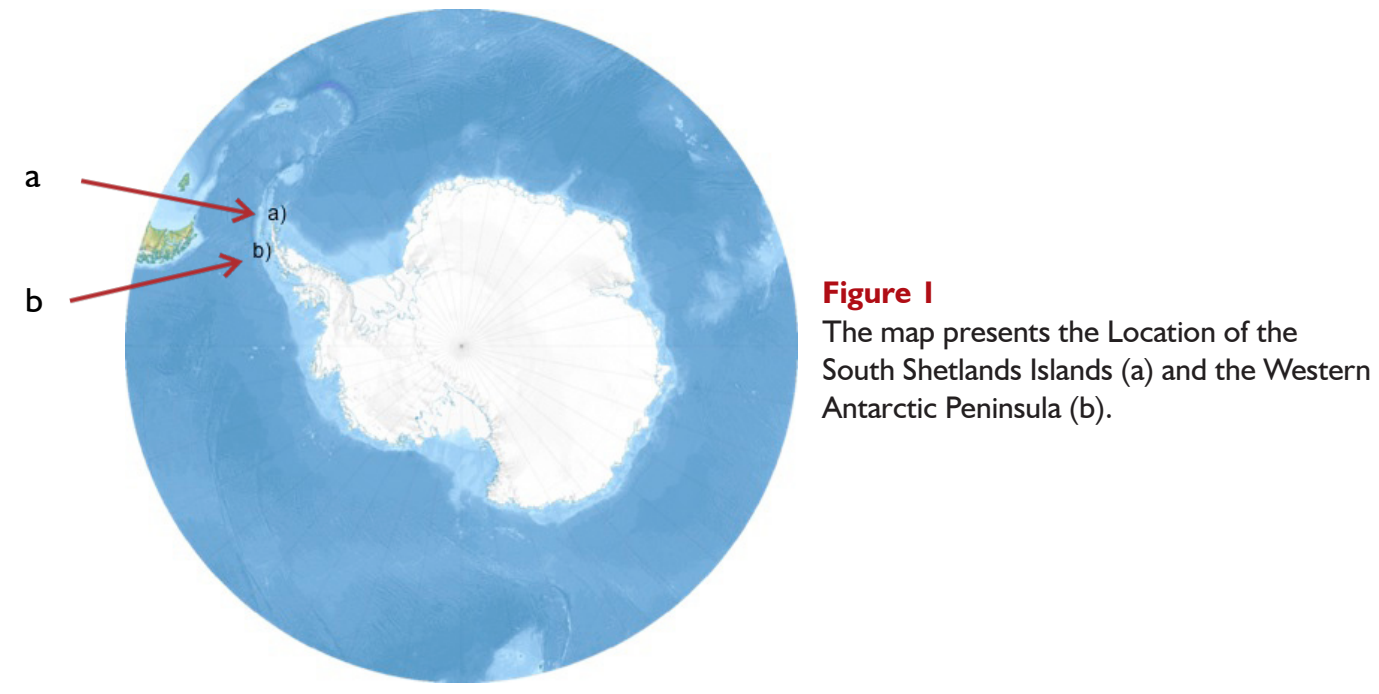

We caught the individuals from both species $-C$. maccormicki and $C$. lonnbergi - and collected at least ten breast feathers of each bird. We stored each sample separately for each individual in labeled paper envelopes or plastic bags and kept it at room temperature until $\mathrm{Hg}$ analyses.

\section{Mercury analysis}

At the lab, we washed approximately $1.0 \mathrm{~g}$ of feathers of each bird with deionized water, EDTA $(0.01 \%)$, and ultrapure water - to remove any exogenously deposited contaminations. Then we dried the samples in an oven $\left(50^{\circ} \mathrm{C}\right)$ overnight and cut each one in small pieces $(1 \mathrm{~mm})$. We divided the samples into three aliquots ( $0.33 \mathrm{~g}$ each) and digested in $5 \mathrm{ml}$ of sulphonitric solution (H2SO4: HNO3; 0,5\%) for three hours in a water bath $\left(60^{\circ} \mathrm{C}\right)$. After dissolution, we added $5 \mathrm{ml}$ of potassium permanganate ( $\mathrm{KMnO} 4 ; 5 \%)$, and the samples stayed $15 \mathrm{~min}$ in the hot bath, then we cooled and neutralized with I $\mathrm{ml}$ of hydroxylamine hydrochloride $(\mathrm{HO}-\mathrm{NH} 3 \mathrm{Cl}+\mathrm{NaCl} ; \mathrm{I} \%)$. We obtained a final volume of $12 \mathrm{ml}$ by adding deionized water to the samples.

We analyzed the samples for total $\mathrm{Hg}$ via atomic absorption spectrophotometry by cold vapor generation (FIMS-400, Perking-Elmer) at the Laboratório de Radioisótopos Eduardo Penna Franca (Federal University of Rio de Janeiro, Brazil). Each 20 samples analyzed was preceded and followed by two blanks, a sample blank and two samples of standard reference material (IAEA 085, human hair provided by the International Atomic Energy Agency). Total $\mathrm{Hg}$ concentrations tare reported as parts per million (ppm) dry weight (dw). Mean percent recoveries for standard reference materials were $95.0 \%+-\mathrm{x} \%$. The detection limit of the assay was $0.005 \%$. 


\section{Statistical analysis}

We averaged the $\mathrm{Hg}$ levels for adults captured twice and tested the normal distribution of data with the Kolmogorov-Smirnoff test. To compare the mean feathers' Hg levels among adults, chicks, and geographical areas, we used the non-parametric Kruskal-Wallis or Mann-Whitney tests. We also used the Dunn test to investigate differences among groups and calculated the Spearman rank correlations among variables. We presented all means followed by Standart Deviation (+-SD) and defined statistical significance at $p<0.05$.

\section{Results}

We analyzed $\mathrm{Hg}$ concentration for $\mathrm{I} 22$ samples of feathers for two species, including 64 adults and 34 chicks for $C$. maccormicki and 16 adults and eight chicks for $C$. lonnbergi (Table I). For adults, the $\mathrm{Hg}$ average concentrations ranged from 0.65 to $9.44 \mathrm{mg} / \mathrm{kg}$ for $C$. maccormicki and between 0.46 to $2.64 \mathrm{mg} / \mathrm{kg}$ for $C$. lonnbergi. We found the highest value of $\mathrm{Hg}$ in an adult of $C$. maccormicki, captured in Potter Cove $(9.44 \mathrm{mg} /$ $\mathrm{kg}$ ). The $\mathrm{Hg}$ levels for chicks were lower than for adults ranged from 0.26 to $1.56 \mathrm{mg} / \mathrm{kg}$ for $\mathrm{C}$. maccormicki and 0.72 to $2.72 \mathrm{mg} / \mathrm{kg}$ for C. lonnbergi.

Table I. Concentration of mercury ( $\mathrm{mg} / \mathrm{kg}$ ) in breast feathers of Antarctic skuas Catharacta maccormicki and C. lonnbergi in three breeding areas in the Antarctic Peninsula. Values represent the mean \pm standard deviation and sample size (n). Presented in the format: mean +- standard deviation (sample number).

\begin{tabular}{ccccc}
\hline \multirow{2}{*}{$\begin{array}{r}\text { Species } \\
\text { Age }\end{array}$} & \multicolumn{2}{c}{ Catharacta maccormicki } & \multicolumn{2}{c}{ Catharacta lonnbergi } \\
\cline { 2 - 5 } Region & Adults & Chicks & Adults & Chicks \\
\hline Admiralty Bay & $\begin{array}{c}3.90 \pm 1.20 \\
(\mathrm{n}=24)\end{array}$ & $\begin{array}{c}0.62 \pm 0.28 \\
(\mathrm{n}=29)\end{array}$ & $1.84 \pm 0.64(\mathrm{n}=5)$ & - \\
Potter Cove & $\begin{array}{c}3.82 \pm 1.99 \\
(\mathrm{n}=18)\end{array}$ & $1.59 \pm 1.31(\mathrm{n}=4)$ & $\begin{array}{c}1.91 \pm 0.90 \\
(\mathrm{n}=10)\end{array}$ & $\begin{array}{c}0.88 \pm 0.79 \\
(\mathrm{n}=8)\end{array}$ \\
Cierva Point & $\begin{array}{c}3.64 \pm 1.91 \\
(\mathrm{n}=24)\end{array}$ & $0.62(\mathrm{n}=1)$ & $1.92(\mathrm{n}=1)$ & - \\
\hline
\end{tabular}

We found significantly higher $\mathrm{Hg}$ levels in adults of $C$. maccormicki compared with adults of $C$. lonnbergi $\left(U^{\prime}=84 \mathrm{I} .00, p<0.0 \mathrm{I}\right)$ and with chicks of both species (Tukey-Kramer, $\left.q>3.398, p<0.0 \mathrm{l}\right)$. We do not find significant differences comparing adults of $C$. lonnbergi with chicks of both species $\left(U^{\prime}=16.00, p<0.05\right)$. When comparing breeding areas we had no significant differences from samples of adults of $C$. maccormicki (Tukey-Kramer $q>3.398, p<0.05$ ) or $C$. lonnbergi $\left(U^{\prime}=62.00, p<0.05\right)$, but we recorded statistical differences in $\mathrm{Hg}$ levels from chicks of $C$. maccormicki caught in different areas $\left(U^{\prime}=106.50, p<0.0 \mathrm{I}\right)$. We recorded the highest $\mathrm{Hg}$ values for birds caught in the Potter Cove area (Table I).

\section{Discussion}

We found no significant differences in $\mathrm{Hg}$ levels obtained to adults samples of the same species from different breeding sites. When we compared species, $C$. maccormicki showed higher levels of $\mathrm{Hg}$ than $C$. lonnbergi. This data can indicate that breeding areas in Antarctica do not represent the most significant source of $\mathrm{Hg}$ for adults, and other factors, e.g., diet and migration, may be associated with the differences we found. The skuas are migrant seabirds, and therefore the results from adults include not only local sources - as feathers represent the cumulative contamination during the reproductive and migratory periods the molt happens once a year for these species; (WATSON, 1975). The detailed process of molt in these birds is unknown, but it is known that the complete molt starts in late February - early March, after the breeding period, and a partial molt in head occurs at the beginning of the breeding period (WATSON, 1975). We can conclude that $\mathrm{Hg}$ levels found in adults' feathers of the studied skuas represent the total exposure of birds to $\mathrm{Hg}$ during the year, expressing $\mathrm{Hg}$ exposure during migratory and breeding periods. 
Although the species have different diets during the breeding period, C. maccormicki is more generalist, feeding mainly on fish, and also in eggs and chicks of penguins and other birds, krill and carcasses of birds and mammals. In the other hand, C. lonnbergi feeding mainly in eggs and chicks of penguins (SANTOS et al., 20 I2; REIS et al. in prep.), their diet during the austral winter (migration period) is little known and probably can be a crucial information to understand the results of the present study to $\mathrm{C}$. maccormicki. The $\mathrm{Hg}$ level varied significantly between adults of two species but did not vary among offspring. The diet during the breeding period could be a variable responsible for differences in $\mathrm{Hg}$ levels. However, as we did not find differences among chicks receiving different diets (as mentioned species feed their chicks differently), our results did not support this. A recent paper on $\mathrm{Hg}$ concentration in muscles of fish Pleurogramma antarcticum, a significant prey resource in the Antarctic marine food web, suggests that predators foraging on this prey are not necessarily at a higher risk of exposure (BRASSO et al., 20I4). The variation presented by Brasso et al. (20I4) for this fish ranged from 0.016 to $0.062 \mathrm{ppm}$ of $\mathrm{Hg}$ and can present a significant variation inter-individual resulting from the broad foraging niche of adult fish. Many species, as $C$. maccormicki, rely almost exclusively on this low trophic level prey during austral summer, and this result could explain the lower $\mathrm{Hg}$ levels we found on offsprings of $C$. maccormicki, as the chicks are fed almost exclusively on fish.

The two species have different migration characteristics during the winter - $C$. maccormicki migrates to Northern Hemisphere, while $C$. lonnbergi remains in the Southern Hemisphere, moving to South America and South Africa (KOPP et al., 20II). The migration area of $C$. lonnbergi presents lower industrial activity and, therefore, lower levels of $\mathrm{Hg}$ than those recorded for the Northern Hemisphere. The mobility of $C$. maccormicki can be a disadvantage when used as bioindicators on a local scale but can be a decisive factor when used on a global scale (BURGER; GOCHFELD, 200I), and they can also be useful for comparisons with no-migratory animals.

Offspring of both species presented significantly lower $\mathrm{Hg}$ levels than adults of $C$. maccormicki, and no differences between chicks of both species and $C$. lonnbergi, which leads us to consider that contamination recorded in chicks is an indicator of local contamination as the source of the food offered to offspring is local. Another critical factor that we need to mention is the influence of contamination transferred through the egg. Intake $\mathrm{MeHg}$ is fast transferred to avian eggs on a dose-dependent basis, making reproduction one of the most sensitive endpoints of $\mathrm{Hg}$ toxicity in birds (WOLFE et al., 1998). As previously mentioned, the diet of these birds in Antarctica has less $\mathrm{Hg}$ available than their diet during the migration period, especially to C. maccormicki. Besides, many seabird species appear to be able to biotransform organic $\mathrm{Hg}$ into less toxic, inorganic forms that can be are stored in the body tissues (THOMPSON; FURNESS, 1989). The half-times calculated to C. skua in experimental design was all over 30 days (Bearhop et al. 2000) what means that until the laying period the $\mathrm{MeHg}$ available in the blood would have been biotransformed and stored in internal tissues - considering that the female arrives in breeding areas in early October. The laying period starts in late November. For this reason, we did not find significant differences in offspring's $\mathrm{Hg}$ levels for both species even when we expected to find higher levels in chicks of $C$. maccormicki as recorded for adults of this species.

We found significant differences comparing offsprings of $C$. maccormicki caught in Admiralty Bay and Potter Cove, both places in King George Island. This information indicates that we can find different levels of contamination in different breeding locations. As we did not find significant differences comparing adults in different sites, the chicks seem to be the best way to investigate local changes in the availability of $\mathrm{Hg}$. We agree that the result should be viewed with caution due to the low number of chicks sampled at Potter Cove $(n=4)$, but we strongly encourage that a more profound investigation should proceed continuously. Even small differences in concentration levels of $\mathrm{Hg}$ may represent a deleterious impact in individuals, especially to young. Whereas migration of $C$. lonnbergi occurs in more restricted areas with lower levels of contamination, we propose that chicks of both species and adults of $C$. lonnbergi can be used as useful indicators of local $\mathrm{Hg}$ contamination to monitor annual changes in the availability of this element in the Antarctic environment.

Comparing our results with those presented by Stewart et al. (1997) to C. skua, Stercorarius parasiticus, we found that $\mathrm{Hg}$ concentration is significantly higher for $\mathrm{C}$. skua than for $\mathrm{C}$. maccormicki, S. parasiticus and $C$. lonnbergi (ANOVA, $p<0.000 \mathrm{I}$ ). This information suggested that $C$. skua is more exposed to contamination than the other species analyzed, which could be explained by differences in dietary habits. The diet of $C$. skua is more varied than for S. parasiticus and includes eels, other poultry, seafood, fish, and fishery discard, while S. parasiticus feeds almost exclusively on eels (STEWART et al., 1997). 
The variation in $\mathrm{Hg}$ levels between the two sampled skuas may be justified mainly by differences in migration patterns. Catharacta maccormicki presented the highest levels of $\mathrm{Hg}$, and it is the species that migrate to more polluted areas. Our results indicate that adults of $C$. maccormicki can be an indicator of global contamination, whereas adults of $C$. lonnbergi and chicks of both species are good indicators of local $\mathrm{Hg}$ contamination, suffering the direct influence of the Antarctic environment. Other factors that may be responsible for interspecific variation in mercury levels in feathers, such as body size, age, molt strategy, diet, migration patterns, physiology, and contamination in breeding or migration areas, should be investigated in future studies.

\section{Acknowledgments}

We thank all members of the projects for assistance during the fieldwork and at lab. This paper contributes to the SCAR State of the Antarctic Ecosystem (AntEco) Research Programme. This study was supported by PROANTAR/CNPq (550040/2007-2 e 557049/2009-I), CNPq (48.4002/20 I I-2) and FAPERJ (E-26/III.505/20I0). E.S.C. (I4I474/2008-4 and I505I5/20I2-0), J.P.M.T (3005II/20I2-4), M.A.S.A. (308792/2009-2) received grants from CNPq, and also from FAPERJ (M.A.S.A. E-26/102.837/20I2 and J.P.M.T. E-26/I02.805/20I2) while preparing this paper. We also thanks Instituto Antártico Argentino/ Dirección Nacional del Antártico for logistic and financial support.

\section{References}

AINLEY, D.G.; RIBIC, C.A.; WOOD, R.C. A demographic study of the South Polar Skua Catharacta maccormicki at Cabo Crozier. J Anim Ecol, 59: I-20, 1990.

AMAP. Arctic Pollution 2002: Persistent Organic Pollutants, Heavy Metals, Radioactivity, Human Health, Changing Pathways. Arctic monitoring and Assessment Programme (AMAP), Oslo, Norway. xii + I I 2p, 2002.

APPELQUIST, H.; ASBIRK, S.; DRABAEK, I. Mercury monitoring: mercury stability in bird feathers. Mar Pollut Bul, I5: 22-24, 1984.

Bargagli, R. Environmental contamination in Antarctic ecosystems. Sci Total Environ, 400: 212-226, 2008.

BLÉVIN, P.; CARRAVIERI, A.; JAEGER, A.; CHASTEL, O.; BUSTAMANTE, P.; et al. Wide Range of Mercury Contamination in Chicks of Southern Ocean Seabirds. PLoS ONE, 8: e54508. doi: I0.1371/journal.pone.0054508, 2013.

BRASSO, R.L.; LANG, J.; JONES, C.D.; POLITO M.J. Ontogenetic niche expansion influences mercury exposure in the Antarctic silverfish Pleuragramma antarcticum. Mar Ecol Prog Ser, 504: 253-263, doi: 10.3354/meps 10738, 2014.

BURGER, J.; GOCHFELD, M. Metal levels in feathers of Cormorants, Flamingos and Gulls from the coast of Namibia in Southern Africa. Environ Monit Asses, 69: 195-203, 2001.

BURGER, J.; GOCHFELD, M. Marine birds as sentinels of environmental pollution. EcoHealth, I: 263-274, 2004.

BURGER, J. Metals in avian feathers: bioindicators of environmental pollution. Reviews in Environmental Toxicology, 5: 203-3II, 1993.

COSSA, D.; HEIMBÜRGER, L.E.; LANNUZEL, D.; RINTOUL, S.R.; BUTLER, E.C.V.; BOWIE, A.R.; et al. Mercury in the Southern Ocean. Geochim Cosmochim Acta, 75: 4037-4052, 201 I.

COSTA, E.S.; ALVES, M.A.S. Climatic changes, glacial retraction and the skuas (Catharacta sp. - Stercorariidae) in Hennequin Point (King George Island, Antarctic Peninsula). Pesq Ant Bras, 5: 163-170, 2012.

FURNESS, R.W.; THOMPSON, D.R.; BECKER, P.H. Spatial and temporal variation in mercury contamination of seabirds in the North Sea. Helgoland Marine Research, 49:605-6I5, 1995.

FURNESS, R.W.; CAMPHUYSEN, C.J. Seabirds as monitors of the marine environment. Journal of Marine Science, 54: 726-737, 1997.

FURNESS, R.W.; LEWIS, S.A.; MILLS, J.A. Mercury levels in the plumage of red-billed gulls Larus novaehollandiae scopulinus of known sex and age. Environ Pollut, 63: 33-39, 1990.

GOEDE, A.A.; de BRUIN, M. The use of bird feather parts as a monitor for metal pollution. Environ Pollut, 8: $281-298,1984$. 
GRANDJEAN, P.; SATOH, H.; MURATA, K.; ETO, K. Adverse effects of methylmercury: environmental health research implications. Environ Health Persp, I I8: I I37-I I45, 2010.

HONDA, K.; NASU, T.; TATSUKAWA, R. Seasonal changes in mercury accumulation in the black-eared kite, Milvus migrans lineatus. Environ Pollut, 42A: 325-334, 1986.

KOPP, M.; PETER, H.-U.; MUSTAFA, O.; LISOVSKI, S.; RITZ; M.S.; PHILLIPS, R.A.; et al. South polar skuas from a single breeding population overwinter in different oceans though show similar migration patterns. Marine Ecology Progress Series, 435: 263-267, $201 \mathrm{I}$.

SCHEUHAMMER, A.M.; MEYER, M.W.; SANDHEINRICH, M.B.; MURRAY, M.W.. Effects of environmental methylmercury on the health of wild birds, mammals, and fish. AMBIO, 36: I2-19, 2007.

SANTOS, M.M.; JUÁRES, M.A.; ROMBOLÁ, E.F.; GARCÍA, M.L.; CORIA, N.R.; DONCASTER, C.P. Over-representation of bird prey in pellets of South Polar Skuas. J Ornithol, I53: 979-983, 2012.

SPROVIERI, F.; PIRRONE, N.; HEDGECOCK, I.M.. Intensive atmospheric mercury measurements at Terra Nova Bay in Antarctica during November and December 2000. J Geophysical Res, I07:4722, doi: I 0. I029/2002JD002057, 2002.

STEWART, F.M.; PHILLIPS, R.A.; CATRY, P.; FURNESS, R.W. Influence of species age and diet on mercury concentrations in Shetland seabirds. Marine Ecological Progress Series, I5I: 237-244, 1997.

THOMPSON, D.R.; FURNESS, R.W. The chemical form of mercury stored in south Atlantic seabirds. Environ Pollut, 60: 305-317, 1989.

THOMPSON, D.R.; HAMER, K.H.; FURNESS, R.W. Mercury accumulation in great skuas Catharacta skua of known age and sex, and its effects upon breeding and survival. J Appl Ecol, 28: 672-684, 1991.

VEERLE, J.; TOM, D.; RIANNE, P.; LIEVEN, B.; RONNY, B.; MARCEL, E. The importance of exogenous contamination on heavy metal levels in bird feathers. A field experiment with free-living great tits, Parus major. J Environ Monitor, 6: 356-360, 2004.

WALSH, P.M. The use of seabirds as monitors of heavy metals in the marine environment. Pp. I83-20I4. In: FURNESS, R.W., RAINBOW, P.S., editors. Heavy metals in the marine environment. Boca Raton: CRC Press; 1990.

WATSON, G.E. Birds of the Antarctic and Sub-Antarctic. Washington: Antarctic Ressearch Series - American Geophysical Union; 1975.

WHO/IPCS. 1976. Environmental Health Criteria 0I: Mercury. World Health Organization/International Program on Chemical Safety. Geneva. I 3 I p. Disponível em <http://et al..inchem.org/documents/ehc/ehc/ehc00 I.htm>. Acesso em: II nov. 2019. 